\title{
Communication
}

\section{Efficient methane electrocatalytic conversion over a Ni-based hollow fiber electrode}

\author{
Zhikai Guo a,b, Wei Chen a,*, Yanfang Song a, Xiao Dong a, Guihua Li a, Wei Wei a,c, Yuhan Sun a,c,\# \\ a CAS Key Laboratory of Low-carbon Conversion Science and Engineering, Shanghai Advanced Research Institute, Chinese Academy of Sciences, \\ Shanghai 201210, China \\ b University of Chinese Academy of Sciences, Beijing 100049, China \\ c School of Physical Science and Technology, ShanghaiTech University, Shanghai 201210, China
}

\section{A R T I C L E I N F O}

\section{Article history:}

Received 25 September 2019

Accepted 16 November 2019

Published 5 July 2020

\section{Keywords:}

Methane

Electrocatalytic conversion

Nickel

Nickel oxide

Hollow fiber

\begin{abstract}
A B S T R A C T
Natural gas and shale gas, with methane as the main component, are important and clean fossil energy resources. Direct catalytic conversion of methane to valuable chemicals is considered a crown jewel topic in catalysis. Substantial studies on processes including methane reforming, oxidative coupling of methane, non-oxidative coupling of methane, etc. have been conducted for many years. However, owing to the intrinsic chemical inertness of $\mathrm{CH}_{4}$, harsh reaction conditions involving either extremely high temperatures or highly oxidative reactants are required to activate the $\mathrm{C}-\mathrm{H}$ bonds of $\mathrm{CH}_{4}$ in such thermocatalytic processes, which may cause the target products, such as ethylene or methanol, to be further converted into coke or $\mathrm{CO}$ and $\mathrm{CO}_{2}$. It is desirable to adopt a new strategy for direct $\mathrm{CH}_{4}$ conversion under mild conditions. Herein, we report that efficient electrocatalytic oxidation of methane to alcohols at ambient temperature and pressure can be achieved using a NiO/Ni hollow fiber electrode. This work opens a new avenue for direct catalytic conversion of $\mathrm{CH}_{4}$.
\end{abstract}

(C) 2020, Dalian Institute of Chemical Physics, Chinese Academy of Sciences. Published by Elsevier B.V. All rights reserved.
Natural gas and shale gas, with methane as the main component, are important and clean fossil energy resources [1-3]. While unconventional natural gas especially shale gas is exploited on a large scale, it is potentially more economical and environmentally friendly to use $\mathrm{CH}_{4}$ directly as a chemical feedstock [4-6]. However, owing to its perfectly stable symmetrical tetrahedral structure, the methane molecule exhibits high $\mathrm{C}-\mathrm{H}$ bond strength (439 kJ/mol), negligible electron/proton affinity, large ionization energy, and low polarizability, resulting in great difficulties in activating methane and breaking $\mathrm{C}-\mathrm{H}$ bonds [7-12]. Therefore, conversion of methane into value-added chemicals remains highly attractive yet challenging, and is considered a crown jewel topic in catalysis. Unlike methane reforming [13-15], where methane is converted only to syngas $\left(\mathrm{CO} / \mathrm{H}_{2}\right)$ as a feedstock for the Fischer-Tropsch synthesis process [16,17], oxidative coupling of methane (OCM) can produce $\mathrm{C}_{2}$ hydrocarbons such as ethylene and ethane and has been studied extensively since the early $1980 \mathrm{~s}$ [18-20]. However, the existence of oxygen $\left(\mathrm{O}_{2}\right)$ at high temperatures causes potential explosion risks and irreversible

\footnotetext{
* Corresponding author. Tel: +86-21-20350954; Fax: +86-21-20350867; E-mail: chenw@sari.ac.cn

\# Corresponding author. Tel: +86-21-20608005; Fax: +86-21-20350867; E-mail: sunyh@sari.ac.cn

This work was supported by the National Natural Science Foundation of China (91745114, 21802160), the Ministry of Science and Technology of China (2016YFA0202800, 2018YFB0604700), Shanghai Sailing Program (18YF1425700), Shanghai Advanced Research Institute Innovation Research Program (Y756812ZZ1, Y756803ZZ1), and Shanghai Functional Platform for Innovation Low Carbon Technology. DOI: 10.1016/S1872-2067(20)63548-3 | http://www.sciencedirect.com/science/journal/18722067 | Chin. J. Catal., Vol. 41, No. 7, July 2020
} 
overoxidation, producing a large amount of $\mathrm{CO}_{2}$ with low carbon utilization in the OCM route [21,22]. Recently, non-oxidative coupling of methane (NOCM) to olefins and aromatics was reported as a promising route $[23,24]$, but the harsh conditions involving high temperatures $\left(\sim 1000{ }^{\circ} \mathrm{C}\right)$ may limit its industrial adoption to some extent [25]. To overcome the disadvantages in the OCM and NOCM routes, it is desired to develop a new approach for direct methane conversion.

Compared to the thermocatalytic routes, the electrocatalytic route for converting methane into chemicals exhibits obvious merits [26-28]: (1) mild reaction conditions, since electrocatalytic methane conversion reactions may occur even at ambient temperature and pressure; (2) easy handling of potential and current, which are key experimental parameters for manipulating reaction kinetics; and (3) the use of renewable electrical energy. Electrocatalytic conversion of methane can be considered as the process of storing renewable electricity as chemical energy. However, electroactive components are crucial for the electrocatalytic conversion of methane, and $\mathrm{Ni}$-based catalysts have been widely reported to be active for methane electroconversion [29,30]. For instance, Fan [29] reported methanol production through electrocatalytic methane oxidation with a $\mathrm{Ni}(\mathrm{OH})_{2} / \mathrm{CoO}(9: 1) / \mathrm{Ag} / \mathrm{C} / \mathrm{CeO}_{2}(85 / 5 / 10)$ anode. Mustain et al. [30] developed a $\mathrm{NiO}-\mathrm{ZrO}_{2}$ bifunctional electrocatalyst with $\mathrm{CO}_{3}{ }^{2-}$ anions for $\mathrm{CH}_{4}$ oxidation, producing $\mathrm{CH}_{3} \mathrm{OH}$, $\mathrm{HCHO}$, and other oxygenates. However, the solubility of methane in electrolyte solutions is quite low, which greatly hampers the electrocatalytic performance. Furthermore, the essential gas-liquid-solid three-phase interfaces cannot be attained in aqueous methane electrooxidation systems. These problems are also encountered during liquid-phase electrochemical reactions involving at least one gas-phase reactant, such as electrochemical $\mathrm{CO}_{2}$ reduction and oxygen reduction reactions.

Herein, we report a porous nickel-based hollow fiber electrode comprising a $\mathrm{NiO}$ active layer on the surface (denoted as NiO@NiHF) for electrocatalytic methane conversion reactions. The hollow-fiber-type electrode possesses compact three-dimensional geometry, which provides a large area and three-phase boundary for methane electrooxidation. A methane gas flow enters a Ni-based hollow fiber from one end while the other end is sealed by epoxy resin; thus, excurrent

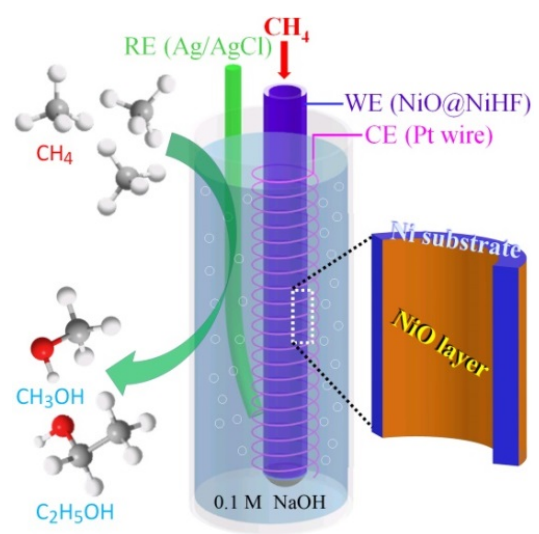

Scheme 1. Schematic illustration of electrocatalytic methane conversion using $\mathrm{NiO} @ \mathrm{NiHF}$ anode. methane must pass through the $\mathrm{NiO} / \mathrm{Ni}$ interface with numerous pores in a $0.1 \mathrm{~mol} / \mathrm{L}$ aqueous $\mathrm{NaOH}$ solution, as shown in Scheme 1 . The products, methanol and ethanol, are efficiently generated at the NiO@NiHF anode with faradaic efficiencies for $\mathrm{CH}_{4}$ oxidation up to $90 \%$ at ambient temperature and pressure. Ni-based hollow fiber electrodes can be prepared via a facile method that is compatible with existing large-scale production processes.

The synthesis of NiO@NiHF composites is mainly divided into two steps: (1) preparation of Ni hollow fiber (NiHF), which involves an improved phase-inversion method to make NiHF with commercial nickel powder as a pristine feedstock (see Supporting Information (SI) for full details), and (2) active $\mathrm{NiO}$ layer fabrication. The as-prepared NiHFs were calcined in air at 200-300 ${ }^{\circ} \mathrm{C}$ to obtain $x \mathrm{NiO} @ \mathrm{NiHF}$ composites, where $x$ represents the $\mathrm{NiO}$ mass percentage.

Figure 1 displays the porous structures and gas permeance behaviors of the NiHFs. The scanning electron microscopy (SEM) images of the inner and outer surfaces of the NiHFs (Fig. $1 \mathrm{a}$ and $1 \mathrm{~b}$ ) show the abundant pores dispersed on these surfaces. The high-magnification SEM images (the insets in Fig. 1a and $1 \mathrm{~b}$ ) further indicate an average pore size in the range of 1-2 $\mu \mathrm{m}$ as well as smooth surfaces. The cross-sectional morphology of a whole NiHF (Fig. 1c) showed characteristic finger-like structures in the outer and inner regions without any visible large microvoids formed. The high-resolution transmission electron microscopy (HRTEM) image of the outer surface of a NiHF (Fig. 1d) shows that a particle with a d-spacing of $2.03 \AA$ corresponds to the (111) lattice fringe of metallic nickel. The permeances of $\mathrm{H}_{2}, \mathrm{CH}_{4}, \mathrm{~N}_{2}$, and $\mathrm{CO}_{2}$ through a NiHF remain almost constant at different pressure drops (Fig. 1e), and the gas permeance is inversely proportional to the square root of the molecular weight (the inset in Fig. 1e), implying that the gas transport mechanism through a NiHF is dominated by Knudsen diffusion.

The surface morphologies of xNiO@NiHF composites are obviously different from those of the NiHFs (Fig. S2). The outer surface roughness of $\mathrm{xNiO@NiHF} \mathrm{is} \mathrm{much} \mathrm{higher} \mathrm{than} \mathrm{that} \mathrm{of} \mathrm{a}$ NiHF, which is attributed to the occurrence of the thermal oxidation of nickel. According to the cross-section image (Fig. 2a), a thin NiO layer is uniformly grown on the nickel substrate. The coarse outer surfaces of xNiO@NiHF improve the access to the
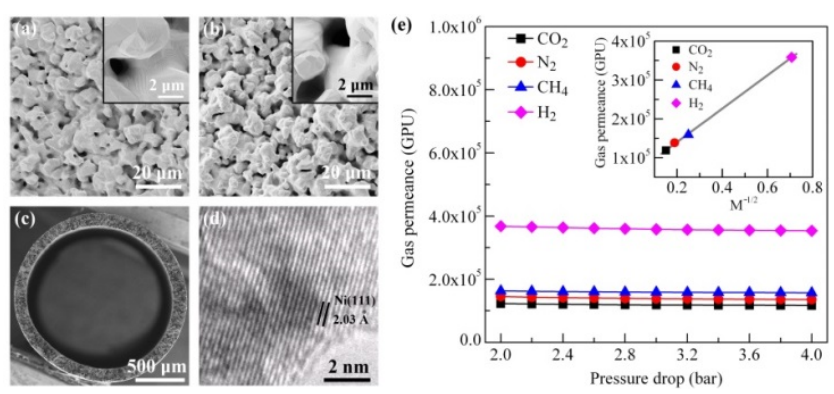

Fig. 1. Characterization of NiHFs. SEM images of the (a) inner and (b) outer surfaces, (c) cross-section of a NiHF, (d) HRTEM image of the outer surface of a NiHF, and (e) gas permeances measured at different pressure drops. The inset in (e) shows the permeance (at 2.0 bar) versus the inverse square root of the molecular weights of individual gases. 

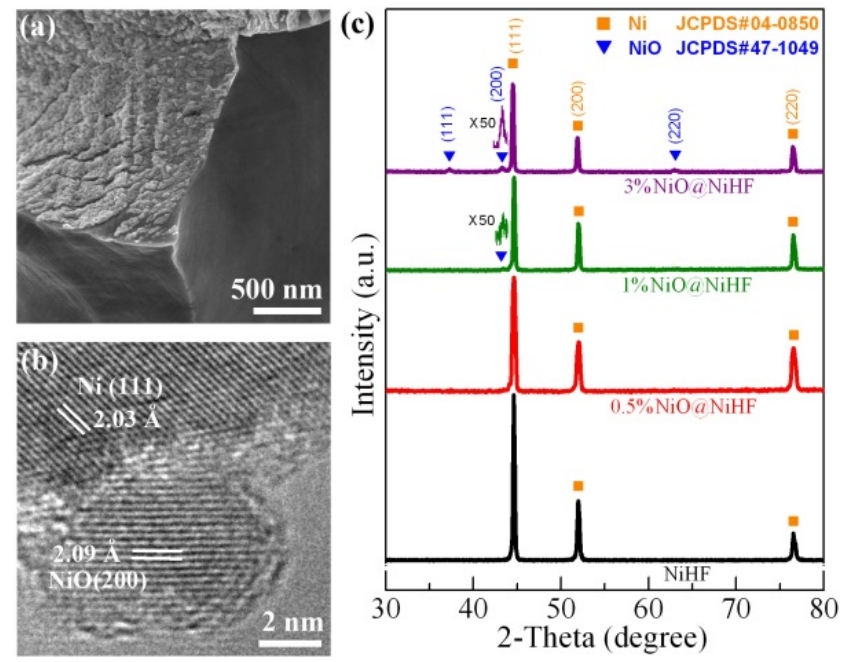

Fig. 2. Characterization of NiO@NiHF. (a) Cross-section SEM and (b) HRTEM images of the outer region of $1 \% \mathrm{NiO} @ \mathrm{NiHF}$ and (c) XRD patterns of NiHFs and xNiO@NiHF composites.

three-phase reaction interfaces, which is beneficial to methane electrooxidation. HRTEM investigation of $1 \% \mathrm{NiO} @ \mathrm{NiHF}$ showed that one particle with a $d$-spacing of $2.09 \AA$ assigned to the NiO (200) plane is adjacent to the metallic Ni substrate, which possesses a $d$-spacing of $2.03 \AA$ corresponding to the metallic Ni (111) lattice fringe (Fig. 2b).

X-ray diffraction (XRD) patterns of the NiHFs and xNiO@NiHF composites in the range of $30^{\circ}-80^{\circ}$ are displayed (Fig. 2c). Diffraction peaks corresponding to the (111), (200), and (220) planes of cubic metallic Ni with a space group of Fm-3m (JCPDS No. 04-0850) are present for all samples. No $\mathrm{NiO}$-related peak was manifested for $0.5 \% \mathrm{NiO} @ \mathrm{NiHF}$, implying only slight thermal oxidation of NiHFs at $200{ }^{\circ} \mathrm{C}$, resulting in the $\mathrm{NiO}$ content being too scarce to be detected by XRD. For $1 \% \mathrm{NiO} @ \mathrm{NiHF}$, in addition to the metallic Ni peaks, a new peak assigned to the cubic $\mathrm{NiO}(200)$ plane with a space group of Fm-3m (JCPDS No. 47-1049) appeared, consistent with the HRTEM observations. With a higher calcination temperature, the intensity of the $\mathrm{NiO}(200)$ peak increased and the other two $\mathrm{NiO}$ peaks corresponding to the (111) and (220) planes also appeared for 3\%NiO@NiHF.

The surface electronic states of the NiHFs and xNiO@NiHF composites were studied by X-ray photoelectron spectroscopy (XPS), as shown in Fig. 3a. The Ni $2 p$ spectrum of the NiHFs shows the main $\mathrm{Ni} 2 p_{3 / 2}$ and $\mathrm{Ni} 2 p_{1 / 2}$ core peaks at binding energies of 852.7 and $870.0 \mathrm{eV}$, respectively, indicating metallic $\mathrm{Ni}$ characteristics. A Ni shake-up satellite $2 p_{3 / 2}$ peak at $858.6 \mathrm{eV}$ also appeared for the NiHFs. As for the xNiO@NiHF composites, in addition to the metallic Ni peaks, new split peaks located at 854.2, 856.3 (Ni $2 p_{3 / 2}$ ), and $871.7 \mathrm{eV}\left(\mathrm{Ni} 2 p_{1 / 2}\right)$ are the characteristic $\mathrm{NiO}$ peaks along with the $\mathrm{NiO}$ satellite $2 p_{3 / 2}$ peak at $861.6 \mathrm{eV}$. Variations of the relative intensity ratios of $\mathrm{NiO} / \mathrm{Ni}$ with respect to the mass percentage of $\mathrm{NiO}$ in the NiHFs and xNiO@NiHF composites are displayed in Fig. 3b. The NiO/Ni ratio was as high as 0.71 in $0.5 \% \mathrm{NiO} @ \mathrm{NiHF}$ while its $\mathrm{NiO}$ content could not be detected by XRD. Moreover, the NiO/Ni ratio continuously increased to 1.09 in $1 \% \mathrm{NiO} @ \mathrm{NiHF}$, but then
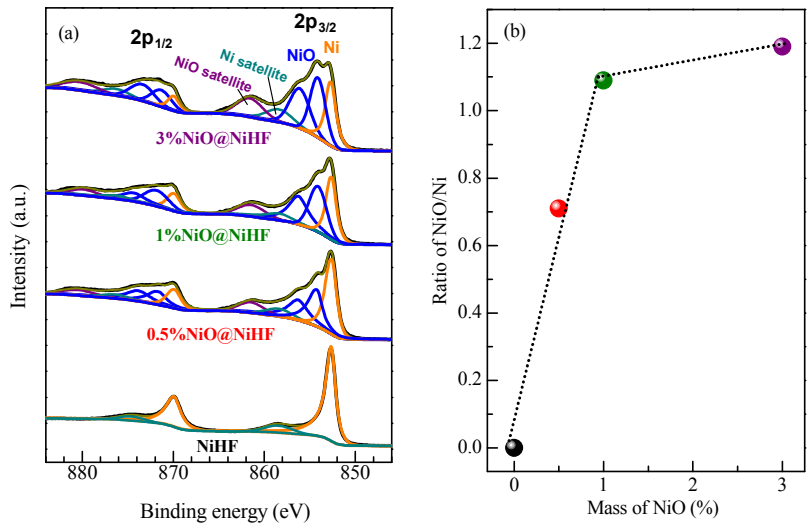

Fig. 3. (a) Ni $2 p$ XPS spectra of the NiHFs and $x$ NiO@NiHF composites, and (b) the relative intensity ratios of $\mathrm{NiO} / \mathrm{Ni}$ versus the mass percentage of $\mathrm{NiO}$.

stepwise up to 1.19 in 3\%NiO@NiHF with a relatively slow rate, implying potential surface/interface configuration inflexion in 1\%NiO@NiHF.

According to the electrochemical impedance spectroscopy (EIS) spectra of the NiHFs and xNiO@NiHF composites (Fig. $4 \mathrm{a})$, the charge transfer resistance $\left(R_{\mathrm{ct}}\right)$ of the NiHFs is $2.4 \Omega$, much smaller than those of $x \mathrm{NiO} @ \mathrm{NiHF}$. The $R_{\mathrm{ct}}$ of $9.6 \Omega$ for $0.5 \% \mathrm{NiO@NiHF}$ monotonically increased to $11.4 \Omega$ for 1\%NiO@NiHF and $19.1 \Omega$ for 3\%NiO@NiHF with increasing $\mathrm{NiO}$ contents. These indicate that the presence of $\mathrm{NiO}$ content significantly hampers the charge transfer owing to its dielectric property. The electrochemically active surface areas (ECSAs) of the NiHFs and xNiO@NiHF composites were determined by using a cyclic voltammetry (CV) method based on their double-layer capacitances. All CV profiles (Fig. S3 and the inset in Fig. 4b) exhibit nearly symmetrical rectangular shapes in the range of 1.21-1.31 V (vs. RHE), indicating the ideal capacitive behaviors of double-layer capacitance. The cathodic and anodic current densities were obtained from the double-layer charge/discharge CV curves at $1.26 \mathrm{~V}$ (vs. RHE). The double-layer capacitance $\left(C_{\mathrm{dl}}\right)$, which is directly proportional to the ECSA, was then calculated by averaging the absolute values of the cathodic and anodic slopes of the linear fits. The $C_{\mathrm{dl}}$ values calculated were $0.4,16.4,24.5$, and $22.8 \mathrm{mF} / \mathrm{cm}^{2}$ for NiHFs, 0.5\%NiO@NiHF, 1\%NiO@NiHF, and 3\% NiO@NiHF, respectively (Fig. 4b). This implies that the ECSA of 1\%NiO@NiHF is the largest, more than sixty times that of the NiHFs. The ECSAs of $0.5 \% \mathrm{NiO} @ \mathrm{NiHF}$ and 3\%NiO@NiHF were about 67\% and $93 \%$ of that of $1 \% \mathrm{NiO} @ \mathrm{NiHF}$, respectively.

Potentiostatic $\mathrm{CH}_{4}$ electrooxidation was carried out in $\mathrm{CH}_{4}$-saturated $0.1 \mathrm{~mol} / \mathrm{L} \mathrm{NaOH}$ (see SI for details), and no product was detected when the NiHFs were used. Both methanol and ethanol were the main products at 1.40-1.50 V (vs. RHE) when the xNiO@NiHF composites were used, while beyond this potential range, the amount of product from $\mathrm{CH}_{4}$ electrooxidation was negligible owing to possible further oxidation of alcohols at higher potentials. As shown in Fig. 5, the faradaic efficiencies (FEs) for methanol generation increased quickly from $1.40 \mathrm{~V}$ and reached a maximum at $1.44 \mathrm{~V}$, followed by dramatic fading at higher potentials. Meanwhile, the ethanol 

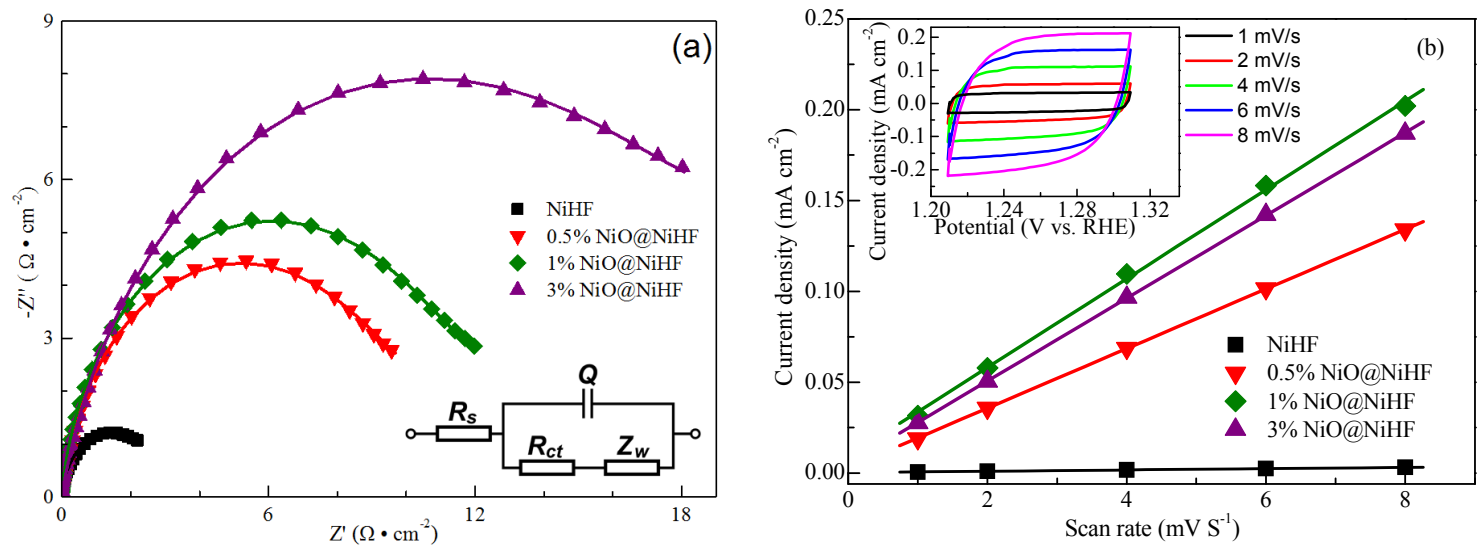

Fig. 4. (a) EIS Nyquist plots of NiHFs and $x \mathrm{NiO} @ \mathrm{NiHF}$ composites at $1.46 \mathrm{~V}$ (vs. RHE) in $\mathrm{CH}_{4}$-saturated $0.1 \mathrm{~mol} / \mathrm{L} \mathrm{NaOH}$. The inset in (a) shows the fitting equivalent circuit. (b) ECSA comparisons for NiHFs and $x \mathrm{NiO} @ \mathrm{NiHF}$ composites based on their double-layer capacitances using CV at different scan rates from 1 to $8 \mathrm{mV} / \mathrm{s}$ in $\mathrm{CH}_{4}$-saturated $0.1 \mathrm{~mol} / \mathrm{L} \mathrm{NaOH}$. The inset in (b) shows the CV curves of $1 \% \mathrm{NiO} @ \mathrm{NiHF}$ in the range of $1.21-1.31 \mathrm{~V}$ (vs. RHE).

FEs reached a maximum at $1.46 \mathrm{~V}$ and then faded rapidly. With increasing potentials, the current densities monotonically increased mildly from 1.40 to $1.46 \mathrm{~V}$ and exponentially after 1.46 V. A possible reason is the oxidation of the nickel substrate at higher potentials. Among the $x \mathrm{NiO} @ \mathrm{NiHF}$ composites, 1\%NiO@NiHF exhibited the highest methanol FE of $54 \%$ at $1.44 \mathrm{~V}$ and the highest ethanol FE of $85 \%$ at $1.46 \mathrm{~V}$. The electrocatalytic performance of $1 \% \mathrm{NiO} @ \mathrm{NiHF}$ remained relatively stable in potentiostatic $\mathrm{CH}_{4}$ oxidation for $180 \mathrm{~min}$ (Fig. S4). This implies that the appropriate $\mathrm{NiO} / \mathrm{Ni}$ configuration is crucial for efficient electrochemical $\mathrm{CH}_{4}$ conversion, which requires a balance between the charge transfer and active oxide sites. In addition, adsorbed $\mathrm{CH}_{4}$ dissociation to form $\mathrm{CH}_{3}{ }^{*}$ at the $\mathrm{NiO} / \mathrm{Ni}$ interface is considered as the initial step for $\mathrm{CH}_{4}$ electrooxidation to methanol and ethanol, as stated in previous reports $[31,32]$. The coupling of $\mathrm{CH}_{3}{ }^{*}$ with its dehydrogenated species $\mathrm{CH}_{2}{ }^{*}$ may be the important step for forming ethanol in an alkaline solution. The related theoretical calculations for speculations on the formation mechanisms of methanol and ethanol through $\mathrm{CH}_{4}$ electrooxidation are underway.

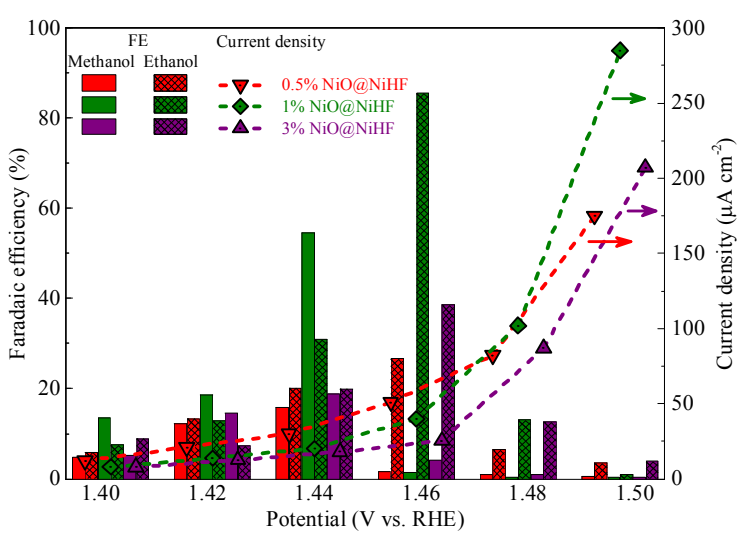

Fig. 5. FEs and current densities of $x \mathrm{NiO} @ \mathrm{NiHF}$ composite catalysts at 1.40-1.50 V (vs. RHE) in $\mathrm{CH}_{4}$-saturated $0.1 \mathrm{~mol} / \mathrm{L} \mathrm{NaOH}$. The FEs were calculated at the steady-state current and product concentrations.
In summary, this work demonstrated the fabrication of a hollow-fiber-type $\mathrm{NiO@Ni} \mathrm{porous} \mathrm{electrode} \mathrm{to} \mathrm{achieve} \mathrm{a}$ methanol FE of $54 \%$ at a current density of $20 \mu \mathrm{A} / \mathrm{cm}^{2}$ and a potential of $1.44 \mathrm{~V}$ (vs. RHE) as well as an ethanol $\mathrm{FE}$ as high as $85 \%$ at a current density of $40 \mu \mathrm{A} / \mathrm{cm}^{2}$ and a potential of $1.46 \mathrm{~V}$ (vs. RHE) for electrocatalytic $\mathrm{CH}_{4}$ conversion. Further experiments and theoretical calculations are underway to explain the $\mathrm{C}-\mathrm{C}$ coupling at the $\mathrm{NiO} / \mathrm{Ni}$ interface of the hollow fiber electrode. The study provides a new pathway for engineering porous electrodes for developing low-cost and highly efficient electrocatalysts for direct methane electrooxidation.

\section{References}

[1] E. W. McFarland, Science, 2012, 338, 340-342.

[2] X. G. Meng, X. J. Cui, N. P. Rajan, L. Yu, D. H. Deng, X. H. Bao, Chem, 2019, 5, 2296-2325.

[3] R. Horm, R. Schlögl, Catal. Lett., 2015, 145, 23-39.

[4] N. J. Gunsalus, A. Koppaka, S. H. Park, S. M. Bischof, B. G. Hashiguchi, R. A. Periana, Chem. Rev., 2017, 117, 8521-8573.

[5] S. J. Xie, S. Q. Lin, Q. H. Zhang, Z. Q. Tian, Y. Wang, J. Energy Chem., 2018, 27, 1629-1636.

[6] Z. S. Zhang, J. W. Li, T. Yi, L. W. Sun, Y. B. Zhang, X. F. Hu, W. H. Cui, X. G. Yang, Chin. J. Catal., 2018, 39, 1228-1239.

[7] P. Tang, Q. J. Zhu, Zhao. X. Wu, D. Ma, Energy Environ. Sci., 2014, 7, 2580-2591.

[8] X. X. Chen, Y. P. Li, X. Y. Pan, D. Cortie, X. T. Huang, Z. G. Yi, Nat. Commun., 2016, 7, 12273.

[9] K. J. Lee, J. L. Dempsey, ACS Cent. Sci., 2017, 3, 1137-1139.

[10] P. Schwach, X. L. Pan, X. H. Bao, Chem. Rev., 2017, 117, 8497-8520.

[11] M. D. Zhao, W. J. Lu, Acta Phys.-Chim. Sin., 2019, 35, 977-988.

[12] V. Paunovic, G. Zichittella, M. Moser, A. P. Amrute, J. Perezramirez, Nat. Chem., 2016, 8, 803-809.

[13] E. Nikolla, J. W. Schwank, S. Linic, Catal. Today, 2008, 136, 243-248.

[14] B. W. Wang, S. C. Albarracinsuazo, Y. J. Pagantorres, E. Nikolla, Catal. Today, 2017, 285, 147-158.

[15] X. D. Feng, J. Feng, W. Y. Li, Chin. J. Catal., 2018, 39, 88-98.

[16] B. C. Enger, R. Lødeng, A. Holmen, Appl. Catal. A, 2008, 346, 1-27. 


\title{
Graphical Abstract
}

Chin. J. Catal., 2020, 41: 1067-1072 doi: 10.1016/S1872-2067(20)63548-3

Efficient methane electrocatalytic conversion over a $\mathrm{Ni}$-based hollow fiber electrode

Zhikai Guo, Wei Chen*, Yanfang Song, Xiao Dong, Guihua Li, Wei Wei, Yuhan Sun *

Shanghai Advanced Research Institute, Chinese Academy of Sciences;

University of Chinese Academy of Sciences; ShanghaiTech University

Electrocatalytic methane conversion was carried out using a porous hollow fiber $\mathrm{NiO} / \mathrm{Ni}$ anode, in which $\mathrm{CH}_{4}$ is converted into methanol and ethanol in a $0.1 \mathrm{~mol} / \mathrm{L}$ aqueous $\mathrm{NaOH}$ solution at ambient temperature and pressure.

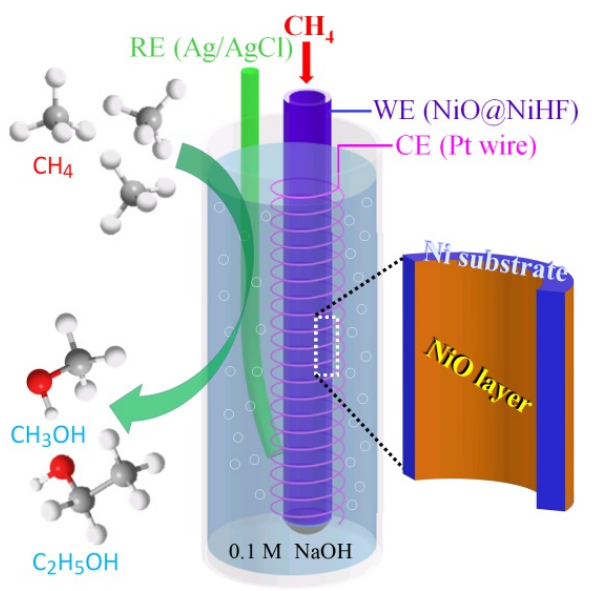

[17] A. I. O. Suarez, À. Szécsényi, E. J. M. Hensen, J. R. Martinez, E. A. Pidko, J. Gascon, ACS Catal., 2016, 6, 2965-2981.

[18] G. E. Keller, M. M. Bhasin, J. Catal., 1982, 73, 9-19.

[19] J. H. Lunsford, Angew. Chem. Int. Ed., 1995, 34, 970-980.

[20] C. Karakaya, R. J. Kee, Prog. Energy Combust. Sci., 2016, 55, 60-97.

[21] C. Mesters, Annu. Rev. Chem. Biomol. Eng., 2016, 7, 223-238.

[22] J. J. Song, Y. N. Sun, R. B. Ba, S. S. Huang, Y. H. Zhao, J. Zhang, Y. H. Sun, Y. Zhu, Nanoscale, 2015, 7, 2260-2264.

[23] X. G. Guo, G. Z. Fang, G. Li, H. Ma, H. J. Fan, L. Yu, C. Ma, X. Wu, D. H. Deng, M. M. Wei, D. L. Tan, R. Si, S. Zhang, J. Q. Li, L. T. Sun, Z. C. Tang, X. L. Pan, X. H. Bao, Science, 2014, 344, 616-619.

[24] D. Soulivong, S. Norsic, M. Taoufik, C. Coperet, J. Thivollecazat, S. Chakka, J. Basset, J. Am. Chem. Soc., 2008, 130, 5044-5045.

[25] T. V. Choudhary, E. Aksoylu, D. W. Goodman, Catal. Rev. Sci. Eng.,
2003, 45, 151-203.

[26] T. J. Omasta, W. A. Rigdon, C. A. Lewis, R. J. Stanis, R. X. Liu, C. Q. Fan, W. E. Mustain, ECS Trans., 2015, 66, 129-136.

[27] M. Ma, B. J. Jin, P. Li, M. S. Jung, J. I. Kim, Y. J. Cho, S. S. Kim, J. H. Moon, J. H. Park, Adv. Sci., 2017, 4, 1700379.

[28] A. Tomita, J. Nakajima, T. Hibino, Angew. Chem. Int. Ed., 2008, 47, 1462-1464.

[29] Q. Fan, U.S. Patent 20150129430 A1, 2015.

[30] N. Spinner, W. E. Mustain, J. Electrochem. Soc., 2013, 160, F1275-F1281.

[31] S. Wu, X. Tan, J. Lei, H. Chen, L. Wang, J. Zhang, J. Am. Chem. Soc., 2019, 141, 6592-6600.

[32] Y. Zhao, H. Wang, J. Han, X. Zhu, D. Mei, Q. Ge, ACS Catal., 2019, 9, 3187-3197.

\section{镍基中空纤维催化剂实现甲烷高效电催化转化}

\author{
郭志凯 ${ }^{\mathrm{a}, \mathrm{b}}$, 陈 为 ${ }^{\mathrm{a},}{ }^{*}$, 宋艳芳 ${ }^{\mathrm{a}}$, 董 笑 ${ }^{\mathrm{a}}$, 李桂花 ${ }^{\mathrm{a}}$, 魏 伟 ${ }^{\mathrm{a}, \mathrm{c}}$, 孙予罕 ${ }^{\mathrm{a}, \mathrm{c}, \#}$ \\ ${ }^{\mathrm{a}}$ 中国科学院上海高等研究院, 中国科学院低碳转化科学与工程重点实验室, 上海 201210 \\ $\mathrm{b}$ 中国科学院大学, 北京 100049 \\ c 上海科技大学物质科学与技术学院, 上海 201210
}

摘要: 随着天然气以及页岩气为代表的非常规天然气的大规模开采, 甲烷作为化工原料的直接转化利用受到了越来越多 的关注. 然而, 甲烷分子具有极其稳定的正四面体结构, 其物理化学性质非常稳定, 如具有高达 $439 \mathrm{~kJ} / \mathrm{mol}$ 的 C-H键能、极弱 的电子亲和力、相当大的离子化能量和低的极化率, 这都使得甲烷分子 $\mathrm{C}-\mathrm{H}$ 键的活化相当困难. 如何实现甲烷直接高效催 化转化被誉为催化领域的“皇冠式”课题. 与经甲烷重整制合成气, 然后通过F-T合成获取化学品的间接转化法相比, 甲烷直 接转化无论在物料、能量转换效率还是在设备成本、环境保护等方面都有着非常明显的优势. 以甲烷氧化偶联以及非氧 化偶联(如无氧芳构化等)为典型代表的甲烷直接转化研究不断取得突破, 但其各自都存在一定的局限性.

相比于热催化转化路径, 电催化转化路径在许多方面存在着十分明显的优势: (1)反应条件温和,甚至在常温常压条件 下也能实现甲烷电催化转化反应的发生; (2) 可调控程度高, 仅需调节关键实验参数如电压和电流等, 就能实现对反应过程 热力学以及动力学的调控; (3) 能够利用可再生电能驱动甲烷转化反应的发生, 可将低品阶的电能转化并存储为化学能.

本文采用 $\mathrm{Ni}$ 中空纤维作为基底, 在其表面构筑 $\mathrm{NiO}$ 活性层, 将 $\mathrm{NiO} @ \mathrm{Ni}$ 中空纤维作为电极, 实现了常温常压条件下的甲 烷电催化转化. 通过X射线衍射、扫描电镜、透射电镜等表征手段, 确定了中空纤维特有的多孔三维结构、气体传输规律、 $\mathrm{NiO}$ 活性层分布状态等物化性质. 通过电化学交流阻抗与循环伏安等测试手段, 获得了电荷传递、电化学活性比表面积等 
电化学性质. 恒电压电氧化甲烷研究发现, 1\% NiO@Ni中空纤维具有最优的催化活性, 分别在 $1.44 \mathrm{~V}$ 与 $1.46 \mathrm{~V}$ (Vs. RHE)电 势下获得 $54 \%$ 的甲醇法拉第效率和 $85 \%$ 的乙醇法拉第效率.

关键词: 甲烷; 电催化转化; 镍; 氧化镍; 中空纤维

收稿日期: 2019-09-25. 接受日期: 2019-11-16. 出版日期: 2020-00-05.

*通讯联系人. 电话: (021)20350954; 传真: (021)20350867; 电子信箱: chenw@sari.ac.cn

\#通讯联系人. 电话: (021)20608005; 传真: (021)20350867; 电子信箱: sunyh@sari.ac.cn 基金来源：国家自然科学基金(91745114，21802160); 国家重点研发计划(2016YFA0202800，2018YFB0604700)；上海市青年科技 英才扬帆计划(18YF1425700); 中国科学院上海高等研究院创新基金(Y756812ZZ1 (172002), Y756803ZZ1 (171003)); 上海市低碳 技术创新功能型平台.

本文的电子版全文由Elsevier出版社在ScienceDirect上出版(http://www.sciencedirect.com/science/journal/18722067). 